\title{
CÂTEVA OBSERVAȚII PRIVIND BRĂȚĂRILE EXECUTATE DIN SÂRME DE BRONZ (SECOLELE X-XIII)
}

Silviu Oța

\section{SOME OBSERVATIONS REGARDING THE BRACELETS MADE OF BRONZE WIRES $\left(\mathrm{X}^{\text {th }}-\right.$ XIII $^{\text {th }}$ CENTURIES)}

\section{Abstract}

The author ties to establish a typology of the bracelets made of bronze wires, as follows:

Type I: Bracelets made of two bronze wires. Each of the bronze wires was bent in two and twisted. At each end of the bracelet there is a curl (Cuptoare-Sfogea, Caransebeş-Centru Gornea-Căunița de Sus, Şopotu Vechi-Mărvilă, Berzovia-Pătruieni Gornea-Zomoniță, Caraş-Severin district, Izvoarele, Mehedinți district, Ferigele, Vâlcea district, Orlea, Olt district, Isaccea, Tulcea district).

Type I a: Bracelets similar with the precedent ones, but decorated in the filigree technique (Şopotu Vechi-Mărvilă, Caraş-Severin district).

Type II: Bracelets twisted, made of a single bronze wire, bent in three, with a curl at one end, the other one being broken (Vărşand-Movila dintre vii, Arad district, Dinogeția, Tulcea district).

Type III: Bracelets made of twisted bronze wires, with tied ends (Vărşand-Movila dintre vii, Arad district, Blandiana- $B$, Alba district).

Type IV: Bracelets made of twisted bronze wires, one end with a curl, the other with a hook.

Type IV a: Bracelet twisted, made of a single bronze wire, bent in three, one end with a hook, the other one beeing broken (Vărşand-Movila dintre vii, Arad district). district).

Type IV b: bracelet made of bronze wires, twisted tight (Mirnopole, Ucraina, Alba Iulia, Alba

Type IV c: Bracelet made of twisted wire, one end with a curl made of two wires. Near the curl there is an ornament. At the other end there is a hook made of single wire (Blandiana, Alba Iulia, Alba district).

Type IV d: Bracelet made of twisted wire, one end with a curl, the other end bent in hook shape (Răducăneni, Alba Iulia).

Type V: Bracelets made of interlaced bronze wires, oneend with a hook, the other probably with a curl (Vărşand-movila dintre vii, Arad district).

Type VI: Bracelets made of twisted bronze wires or made of bronze bar which imitates twisted wire, with zoomorphic ornaments each end.

Type VI a: Bracelet made of twisted bronze wires. Both ends are decorated with animal heads (Vărşand-Movila dintre vii, Arad district, Timişoara-Cioreni, Timiş district, Alba Iulia, Alba district).

Type VI b: Bracelet made of bronze bar which imitates twisted wire, with tied zoomorphic ends (Kovács 3 b type; Mâsca, Arad district, Oradea, Bihor district, Vărşand, Arad-Câmpul din afara cetăţii, Arad district, Moldoveneşti, Cluj district)

Type VI c: bracelet made of mouled bronze bar, which imitates twisted wire, with separated zoomorphic ends (Vărşand-Movila dintre vii, Arad district, Foeni, Bihor district, Dinogeția, Tulcea district).

Type VI d: bracelet made of bronze bar which imitates twisted wire, with tied zoomorphic ends (Kovács 4 b type; Roiori, Bihor district). The inner surface is flat (withoutincisions). Only the exterior surface is decorated with perpendicular incisions.

Cuvinte cheie: morminte, brățări, sârme, necropole

Keywords: graves, bracelets, wires, necropoles 
Pe teritoriul României, Republicii Moldova şi în Bucovina (Ucraina) au fost descoperite în decursul timpului mai multe tipuri de brățări din sârme de bronz torsionate, împletite, sau din bară de bronz care imită torsionarea. În cele ce urmează, vom încerca realizarea unui repertoriu al lor şi o tipologie în funcție de caracteristicile fiecăreia. Pentru acest repertoriu am selectat doar cele mai simple piese din punct de vedere al execuției. De asemenea, aş dori să încerc şi surprinderea contextului din care au fost recuperate şi eventual atribuirea lor unui anumit spațiu în care au circulat. Analiza mea pleacă în principal de la piesele descoperite pe teritoriul Banatului românesc. Deşi această metodă de lucru nu este cea mai corectă, pentru că granițele actuale nu corespund realităților politice ale secolelor X-XIII, precizez că am vrut mai degrabă să realizez un repertoriu şi o tipologie a acestor piese pentru teritoriul actual al României, Republicii Moldova, Bucovina şi partea sudică a Moldovei istorice, actual în Ucraina. Am plecat în analiza mea de la piesele din sudul Banatului deoarece aici s-au creat anumite confuzii în ceea ce priveşte tipologia acestor piese şi în analogiile care s-au oferit uneori pentru ele. De asemenea s-au creat anumite confuzii între piese aparent foarte asemănătoare, dar la care din punct de vedere cronologic şi a ariei de circulație a lor se pot sesiza anumite diferențe (la care mai putem adăuga diferențe în modul de execuție şi în ultimă instanță, în aspectul lor exterior). Tipologia aceasta, prezintă inconvenientul că în viitor, foarte probabil, vor mai apare şi alte tipuri de brățări torsionate (ca de exemplu, cele cu bucle la ambele capete iar în interiorul lor a fost lăsat capătul sârmei şi care a fost îndoit în formă de spirală), care momentan au fost descoperite doar în țările vecine (Ungaria, Banatul iugoslav). În Banatul iugoslav şi în comitatul Csongrád, în zona sa de sud care înglobează colțul de NV al Banatului, astfel de piese au fost descoperite la SzőregHomokbánya, Novi Kneževac şi Bočar.

Până în prezent, tipologii ale brățărilor din secolele X-XIII, sau pe perioade mai restrânse de timp din acest interval cronologic, sunt foarte puține. Aş remarca în acest sens, demersurile efectuate de către J. Giesler (Austria; vezi J. Giesler, Untersuchungen zur Chronologie der
Bjelo Brdo Kultur. Ein Beitrag zur Archäologie des 10. und 11. Jahrhunderts im Karpatenbecken, în Prähistorische Zeitschrift, 56, 1, 1981, Bonn), L. Kovács (Ungaria; vezi L. Kovács, Das Früharpadenzeitliche Gräberfeld von Szalbocs, în V.A.H., VI, 1994) şi colegii de la Muzeul Național al Unirii din Alba Iulia (A. Dragotă et alii). Primul dintre ei a realizat o tipologie sumară a acestor piese, făă a lua în calcul şi alte subvariante regionale. De altfel, scopul lucrării sale nici nu a fost acela de a realiza o tipologie amănunțită a acestor piese, iar teritoriul investigat este în bună parte altul. Cel de-al doilea, şi-a concentrat studiul asupra pieselor din bazinul Carpatic, studiind exclusiv piesele care au avut terminațiile cu motive zoomorfe. Această tipologie a lor, este şi cea mai amănunţită asupra acestui tip de podoabe. Nu în ultimul rând, trebuie remarcat şi efortul colegilor de la Alba Iulia, care au încercat o tipologie asupra principalelor tipuri de brățări din Bazinul Carpatic, datate în secolele X-XI (Dragotă et alii 2003, p. 89-112).

În necropolele din sudul Banatului (Cuptoare-Sfogea, Gornea-Căunița de Sus, Şopotu Vechi-Mârvilă), au apărut două tipuri de brățări din sârme de bronz torsionate. Ambele tipuri au în linii mari acelaşi aspect, ceea ce le diferențiază fiind doar o sârmă de argint sau de bronz filigranat introdusă şi ea prin torsionare printre sârmele de bază ale brățării. Primul tip, a fost executat din două sârme de bronz, fiecare dintre ele îndoită de două ori, în părți egale. Aceste sârme îndoite cum am precizat, se puneau în aşa fel încât buclele formate prin îndoirea lor să fie câte una la fiecare capăt. Apoi se strângeau (sau se apropiau) sârmele şi se torsionau, fiecare capăt în direcția opusă celuilalt. Rezulta astfel o brățară din sârme torsionate, cu câte un ochi sau o buclă la fiecare capăt, în care se aflau terminațiile celor două sârme. Această variantă este cea mai răspândită şi a fost descoperită la Cuptoare-Sfogea, Gornea-Căunița de Sus şi Şopotu Vechi-Mârvilăa Al doilea tip este similar cu primul, dar printre sârmele de bază se introduceau sârme foarte subțiri de metal torsionat. Brățări de acest tip au fost descoperite doar în necropola de la Şopotu Vechi-Mârvilă. Torsionarea se realiza mai mult sau mai puțin 
strâns. În unele situații capetele brățărilor au fost aplatizate cu ciocanul.

\section{Repertoriul descoperirilor pe tipuri de piese şi pe regiuni}

Tip I (Pl. I/1-14; Pl. II/15-29; Pl. V) Brățări din două sârme de bronz, fiecare îndoită în două, alăturate şi torsionate. La fiecare capăt este câte o buclă (Pentru descrierea amănunțită vezi supra)

Banat, aceste brăţări au fost descoperite în morminte sau în necropole, după cum urmează:

1. Cuptoare-Sfogea (Jud. CaraşSeverin). Piesele au fost publicate în bloc şi nu pot fi departajate pe morminte) (Pl. I/1-10).

a. M.8 - mormânt individual, de inhumație; sex feminin; brațele depuse pe piept. Inventar: trei brățări din sârme de bronz, torsionate, o brățară de sticlă, doi cercei de argint decorați în tehnica filigranului. $\mathrm{Nu}$ are ilustrație (Uzum 1981, p. 190; Țeicu 1993, p. 232).

b. M.30 - mormânt individual, de inhumație; sex feminin (?). Inventar: trei brățări din sârme de bronz torsionate. Nu are ilustrație (Uzum 1981, p. 190; Țeicu 1993, p. 232).

c. M.41 - mormânt individual de inhumație, a avut în inventarul funerar un număr neprecizat de brățări din sârme de bronz torsionate şi unul sau doi cercei cu mulură pe verigă (Uzum 1981, p. 188, 190; Uzum 1987, p. 296).

d. M.92 - mormânt individual de inhumație, orientat V-E; brațul drept pe abdomen, iar stângul cu palma pe bazin; suprapus de M.85 şi 86 (ambele fără inventar) fără să fi fost deranjat. Inventar: doi cercei de argint cu astragali şi patru brățări din sârme de bronz torsionate. Nu are ilustrație (Uzum 1987, p. 296; Țeicu 1993, p. 232).

e. M.106 - mormânt individual de inhumație, orientat V-E; sex feminin (?); mâna dreaptă pe abdomen, iar stânga pe bazin. Inventar: inel cu decor zoomorf şi o brățară din sârme de bronz torsionate. Fără ilustrație (Uzum 1975; Țeicu 1993, p. 233). f. M.291-mormânt individual de inhumație; sex feminin; palmele depuse pe bazin. Inventar: nasture descoperit sub torace, verigă de păr cu un capăt îndoit în formă de S, inel de tâmplă cu astragali, două brățări din sârme de bronz torsionate la mâna dreaptă şi una la cea stângă (Uzum 1987, p. 289, 296-298, 307).

g. M.303-mormânt individual de inhumație; adult; brațul drept pe abdomen, iar stângul pe torace. Inventar: o brățară din sârme de bronz torsionate. $\mathrm{Nu}$ are ilustrație (Uzum 1987, p. 289, 307; Țeicu 1993, p. 234).

h. O brățară a fost publicată fără a se preciza dacă provine dintr-un mormânt sau nu (S II/1985, caroul B3, -0,30 m, M.B.M.R. Inv. A 55730)

i. Două brăţări provenite din acelaşi loc, cu numerele de inventar A 55728, A 55729 (Uzum 1987, p. 307).

Severin)

2. Caransebeş-Centru (Jud. Caraş-

a. M.6-mormânt individual de inhumație, orientat probabil vest-est (autorul cercetării menționează est-vest, dar probabil este o greşeală ?!). Descrierea exactă a piesei nu este dată, dar este menționat pentru analogie o piesă provenită din M.306 de la CuptoareSfogea). Mormântul 306, din localitatea menționată nu are însă în inventarul funerar vreo brățară. Deoarece în articolul amintit (Uzum 1987, p. 281-315) nu se dă nici un număr de inventar menționat de P. Bona (Bona 1993, p. 93), bănuim că este vorba de o greşeală de tipar. Este posibil ca în realitate să fie piesa din M.106, care a avut ca inventar o brățară din sârme de bronz torsionate (Țeicu 1993, p. 233; Țeicu 1982, p. 273).

\section{Severin)}

3. Gornea-Căunița de Sus (Jud. Caraş-

a. M.44 - mormânt individual de inhumație; orientat NV-SE; sex feminin; brațele flectate din coate, cu palmele pe clavicule. Inventar: inel cu decor zoomorf, verigă de tâmplă cu astragali, colier de mărgele, scoici kauri, pandantiv clopoțel şi o brățară din sârme de bronz torsionate (Pl. I/11) (Uzum 1981, p. 185, 188, 189, 190, 192, 209, Fig. 15-b, 210-a, b). 
b. M.48 - mormânt individual de inhumatie; orientat NV-SE; sex feminin; adult; brațele aşezate pe torace. Inventar: colier de mărgele şi scoici, două brățări din sârme de bronz torsionate (P1. I/12-13) la mâna dreaptă şi verigă de păr cu un capăt în formă de $S$ (Lazarovici, Maxim, Țeicu, Oprinescu 1993, p. 297, Fig. 14, p. 317, Fig. 16/3, p. 318, Fig. 17/4).

c. M.59 - mormânt individual de inhumație; orientat SV-NE; sex feminin; adult II; mâna dreaptă cu palma pe bazin, iar stânga pe torace. Inventar: două brățări din sârme de bronz torsionate (Pl. I/14; Pl. II/15) la mâna dreaptă, doi cercei de tâmplă din argint cu montură biconică (Lazarovici, Maxim, Țeicu, Oprinescu 1993, p. 298-299, Fig. 14, p. 318, Fig.17/1-3).

4. Şopotu Vechi-Mărvilă (Jud. CaraşSeverin)

a. M.10 - mormânt individual de inhumație, deranjat. Inventar: brățară din sârme de bronz torsionate (P1. II/16) (Țeicu 1993, p. 263, Fig.6/9).

b. M.12 - mormânt individual de inhumație; orientat NV-SE; sex feminin; brațele pe lângă corp. Inventar: la craniu doi cercei de tâmplă cu montura biconică, pe brațe trei brățări din sârme de bronz torsionate (Pl. II/17-19) şi una din bară triunghiulară în secțiune, având capetele lăţite şi decorată prin incizii punctiforme şi linii (Țeicu 1993, p. 241, 263, Fig-6/3-8).

c. M.16 - mormânt individual de inhumație, deranjat, orientat $\mathrm{V}$-E, brațele pe lângă corp; inventar: brățară din sârme de bronz (?-piesa este necurățată, Pl. II/20) cu fir de argint filigranat (Țeicu 1993, p. 263, Fig-6/11).

d. M.27 - mormânt individual de inhumație, deranjat; orientat V-E. Inventar: o brățară din sârme de bronz torsionate (P1. II/21), găsită la mâna stângă, doi cercei de tâmplă din argint, cu montură globulară (! În plic, la M.B.M. - Reşița am găsit un cercel cu montură globulară şi unul cu astragali; Țeicu 1993, p. 241). În publicațiile referitoare la ultima piesă (cercel cu astragali) există mai multe inadvertențe. Prima ar fi aceea că în anul 1993, ea nu a fost menționată în inventarul mormântului 27. De asemenea, în anul 2003, în catalogul mormintelor de la Şopotu Vechi există aceeaşi omisiune. La pagina 37 a aceluiaşi articol este amintită totuşi piesa ca făcând parte din inventarul său. Nici ilustrația de la pagina $56 \mathrm{nu}$ corespunde catalogului mormintelor (Țeicu 2003, p. 56). Având acces la manuscrisul original cu ilustrația aferentă, precum şi la piesele din depozitul tezaur al M.B.M. Reşița, pot spune că piesa a aparținut acestui mormânt. De asemenea, nu este vorba de doi cercei de tâmplă cu montură biconică, ci de unul singur, deformat. Pe planul de săpătură, la M.27 au fost descoperiţi doi cercei, nu trei, cât ar reieşi dacă am lua în considerație doi cercei globulari şi unul cu astragali.

e. M.28 - mormânt individual de inhumație; orientat SV-NE; deranjat. Inventar: cercel de tâmplă cu două muluri pe verigă şi o brățară din sârme de bronz torsionate (Pl. II/22).

5. Timişoara - colecția Muzeului Banatului - în colecțiile muzeului sunt înregistrate mai multe piese de acest tip provenite probabil din sudul Banatului (Pl. II/23-24) (T,eicu 1981, p. 493, Fig. 3/1-2, p. 496, 499, Fig. 7, Fig. 8). În aşezări, astfel de piese, au mai fost descoperite la BerzoviaPătruieni (Țeicu 2003, p. 34).

6. În aşezarea de la Gornea-Zomoniță a mai fost descoperit un fragment de la o astfel de brățară (Țeicu, Lazarovici 1996, p. 59).

\section{Oltenia}

1. Izvoarele (Com. Gruia, Jud. Mehedinți) - piesă provenită din achiziţie (Toropu 1976, p. 176; Dumitriu 2001, p. 127).

2. Ferigele (Com. Costeşti, Jud. Vâlcea) - piesă (Pl. II/25) provenită prin achiziție (Dumitriu 2001, p. 123, Taf. 93/14; Vulpe 1967, p. 186 Taf. XXVI/31; Toropu 1976, p. 17).

3. Orlea (Com. Orlea, Jud. Olt), (Pl. II/26) (Dumitriu 2001, p. 132, Taf. 97/5).

4. Drobeta Turnu Severin (Jud. Mehedinţi) - piesă din colecția Istrati-Capşa (P1. II/27) (Dumitriu 2001, p. 123, Taf. 86/11).

\section{Dobrogea}

5. Isaccea (Jud. Tulcea), (P1. II/28-29)

(Dumitriu 2001, p. 65, 108, Taf. 72/6, 73/15). 
Tip Ia - Brățări similare cu precedentele, dar sunt ornamentate în tehnica filigranului (Pl. V).

\section{Banat}

1. Şopotu Vechi-Mârvilă (jud. CaraşSeverin)

a. M.46 mormânt individual, de inhumație; din schelet s-au mai păstrat doar câteva resturi de oase; deranjat de o groapă modernă. Inventar: două brățări din sârme de bronz torsionate, $\mathrm{cu}$ ochiuri la capete. Printre sârmele torsionate, au fost introduse fire de argint filigranate (Pl. III/30-31).

Piese din sârme de bronz torsadate sau care să imite torsionarea au mai fost descoperite pe teritoriul țării noastre, însă în diverse alte variante. Aceste variante sunt:

Tip II - Brățări torsadate, dintr-o sârmă de bronz îndoită în trei, cu buclă la capăt, celălalt capăt fiind rupt (Pl. VI)

\section{Crişana} Arad)

1. Vărşand-Movila dintre vii (jud.

a. M.52 - (Pl. III/32) mormânt individual de inhumație, orientat NV-SE, cu mâna dreaptă pe bazin iar stânga pe lângă corp, a mai avut ca inventar încă o brățară de bronz de tip neprecizat, trei vârfuri de săgeți din fier, la stânga bazinului, mâner de pumnal din fier, la dreapta bazinului şi un inel din bronz de tip neprecizat, descoperit la mâna stângă (Popescu 1956, p. 132, Fig. 88/1; M.N.I.R. Inv. Nr. 17211).

b. A doua brăţară $(\mathrm{Pl}$. III/33) provine dintr-o achiziție (M.N.I.R. Inv. Nr.17203, 17150; Oța 1998-2000, p. 502, Fig. 18).

\section{Dobrogea}

2. Dinogeția (jud. Tulcea) (Pl. III/34). Trebuie precizat că la piesele similare descoperite în sudul Dunării, la BraničevoSvetinia, o piesă a avut un capăt lipsă, iar cealaltă, la capătul opus, se termina tot cu o buclă (Dumitriu 2001, p. 106, Taf. 64/6).

Tip III - Brățară din sârme de bronz torsionate cu terminațiile legate (Pl. VII).

\section{Crişana}

Arad)

1. Vărşand-Movila dintre vii (jud.

a. M. 15 - (M.N.I.R. Inv. Nr.17197) (Pl. III/35) mormânt individual de inhumație, orientat NV-SE; brațele aşezate pe lângă corp cu palmele aduse pe abdomen; a mai avut ca inventar o brățară de platbandă de bronz, iar capetele rotunjite şi perforate, găsită la mâna dreaptă, altă brățară din tablă de bronz descoperită la aceeaşi mână, un inel din bronz ale cărui capetele au fost suprapuse, descoperit pe torace, buton din bronz cu tortiță, descoperit tot pe torace, două verigi de păr din bronz descoperite în regiunea craniului, buton $\mathrm{cu}$ tortiţă din două emisfere şi cercel din argint cu un capăt îndoit în formă de S (Popescu 1956, p. 129, Fig. 83/2, Popescu 1970, p. 54).

\section{Transilvania}

1. Blandiana-B (jud. Alba)

a. M. 1 (a aparținut unei femei). Acesta mai conținea pe lângă cele două brățări ( $\mathrm{Pl}$. III/36-37) un inel cu piatră, o brățară din bară decorată la capete, doi cercei din argint decorați în tehnica granulației şi filigranului, un nasture şi o bucată de tablă de fier (Horedt 1966, p. 276, 278, Abb. 18/1-7, p. 279, Abb. 19, Ciugudean, Dragotă 2002, p. 54, Fig. 132-133).

Tip IV - Brățări din sârme de bronz torsionate, terminate cu buclă, respectiv cârlig la capete. La aceste piese se constată mai multe subvariante, în funcție de modul de execuție (Pl. VIII).

IV.a. Brățară torsionată, dintr-o sârmă de bronz îndoită în trei, cu cârlig la capăt, celălalt capăt fiind rupt.

\section{Crişana}

1. Vărşand-Movila dintre vii (jud. Arad). A fost achiziționată (M.N.I.R. Inv. Nr. 17198) (Pl. III/38) (Oța 1998-2000, p. 502, Fig. 17).

IV.b. Brățară din sârme de bonz, torsionată strâns. 
Basarabia sudică (actual Ucraina)

\section{Mirnopole.}

Un capăt este rupt, iar celălalt este sub formă de buclă mică, din o singură sârmă (Pl. III/39). Piesa provine dintr-un mormântal cărui inventar pare amestecat cu piese provenite din altul. Autorul lucrării presupune că din acest mormânt provin, pe lângă brățară, doar un fragment de țesătură aurită şi două discuri de corn (Spinei 1985, p. 112, 200, Fig.28/1).

\section{Transilvania}

1. Alba Iulia

A fost descoperită o altă piesă, asemănătoare (Pl. III/40) (Horedt 1958, p. 52, 56, Abb. 13/5), dar are ambele capete rupte (!?).

IV.c. Brățară din sârmă torsionată, terminată la unul din capete cu buclă din sârmă dublată; pe fața ei este un decor; celălalt capăt este în formă de cârlig din sârmă simplă.

\section{Transilvania}

1. Blandiana. Acest tip de piesă a fost recuperat în 1910 (Pl. III/41) (Horedt 1966, p. 276, Abb.15/4; Horedt 1958, p. 113, Abb.31/4).

2. Alba Iulia. Este o piesă asemănătoare cu precedenta ca mod de execuție şi decor. Sistemul de închidere, conform descrierii, este diferit, prin două cârlige. Nu este exclus să fie vorba de o degradare a piesei, sistemul menționat fiind puțin utilizat (Plantos 2003, p. 52).

IV.d. Brățări din sârme de bronz torsionate, terminate la unul din capete $\mathrm{cu}$ o buclă, iar la celălalt cu un cârlig format prin îndoirea corpului torsionat al brățării.

\section{Moldova}

1. Răducăneni - o piesă provine din aşezare (Pl. III/42) (Spinei 1985, p. 212, Fig. 40/8).

\section{Transilvania}

1. Alba Iulia

a. M.14 - două piese. (Pl. III/43) (Ciugudean 1996, p. 21, 26, Fig. 34, 35; Ciugudean, Dragotă 2002, p. 42, Fig. 77).

b. M.11 - o piesă (Ciugudean 1996, p. 21, 26, Fig. 36). În mormânt a mai fost descoperită şi o verigă de bronz care avea capetele desfăcute.

O brățară torsadată dintr-o sârmă de bronz pliată în trei (?), ale cărei capete sunt rupte a fost descoperit la Vărşand-Movila dintre vii (Pl. III/44; Pl. XI) în cercetări de la începutul secolului XX (Fehér, Éry, Kralovánsky, 1962, 82). Ea nu poate fi însă încadrată vreunui tip sau sub-tip anume, asemeni exemplarului descoperit la Moftinu Mic-Messzelátó domb (jud. Satu Mare) (Pl. IV/45; Pl. XI) (Németi 2001, p. 227, 2. kép. 15; Németi 1986/1987, p. 101-137) sau a celui provenit dintr-o localitate necunoscută din nordul Bucovinei (Pl. IV/46; Pl. XI) (Spinei 1997, p. 151, fig. 9/20).

Tip V - Brățări din sârme de bronz împletite terminate cu cârlig şi probabil ochi la capete (Pl. IX).

\section{Crişana}

1. Vărşand-movila dintre vii, (jud. Arad) - două fragmente (PL. IV/49-50). Alte două brățări care au avut însă unul dintre capete rupt (Pl. IV/47-48), iar celălalt este în formă de ochi provin din aceeaşi necropolă. M.M.I.R. Inv. Nr. 17205, 17205, 17207, 17201 (Oța 1998-2000, p. 501-502, Fig. 13-16).

Tip VI - Brățările din sârme de bronz torsionate, sau din bară de bronz care imită torsionarea (Pl. X), cu terminații decorate cu motive zoomorfe cuprind mai multe sub-tipuri (Pentru răspândirea în interiorul bazinului carpatic a tipurilor de brățări decorate cu motive zoomorfe pe tipuri, vezi Kovács 1994):

VI.a. Brățară din sârme de bronz torsionate cu terminații în formă de capete de animal (M.N.I.R. Inv. NR. 17213) au fost descoperite la:

\section{Crişana}

1. Vărşand-Movila dintre vii (jud. Arad)

a. M.2 - (P1. IV/51) mormânt individual de inhumație, orientat V-E, cu palmele aduse sub bazin; ca inventar este posibil să mai fi avut şi un inel subțire din tablă de bronz care are capetele suprapuse (Popescu 1956, p. 128, Fig. 81/2, M.N.I.R. Inv. Nr. 17213). Este tipul 3a Kovács (Kovács 1994, p. 123. Autorul 
articolului aminteşte două brățări din tipul 3a, dar una dintre ele este în realitate din tipul 4a, cea cu numărul de catalog 54).

\section{Banat}

1. Timişoara-Cioreni (jud. Timiş); piesa a fost recuperată din necropolă $(\mathrm{Pl}$. IV/52) (Rădulescu, Gáll 2001, p. 155, 158, Abb. 3/1) şi se încadrează tipului 3a Kovács.

\section{Transilvania}

1. Alba Iulia (jud. Alba); piesele provin din cercetări de la începutul secolului XX (Pl. IV/53-54) (Horedt 1958, p. 52, 55, Abb.12/1, 3). Acestea se încadrează în tipul 3a Kovács (Kovács 1994, p. 123).

VI.b. Brăţară din bară de bronz care imită torsionarea, decorată cu motive zoomorfe, unite între ele.

\section{Crişana}

1. Mâsca (jud. Arad); de acolo au fost recuperate mai multe piese, printre care scărițe de şa, zăbale şi brățări cu terminațiile decorate cu motive zoomorfe Pl. IV/55) (Bálint 1991, p. 241; Réthy 1898, p. 127/II.tábla/2, 128; Kovács 1994, p. 125; este vorba de tipul 3b Kovács; Kovács 1994, p. 125).

2. Oradea (jud. Bihor) (Pl. IV/56) (Hampel 1900, p. 666, Taf.75/15, p. 667; Kovács 1994, p. 125) - tipul 3b Kovács.

3. Vărşand (jud. Arad) - tipul 3b Kovács (Kovács 1994, p. 123. Descoperirea este din 1930).

\section{Banat}

4. Arad-Câmpul din afara cetății (Jud. Arad) - au fost recuperate mai multe piese de inventar din secolele X-XI (pandantiv lunulă, verigi de păr simple, cu un capăt îndoit în formă de $\mathrm{S}$, inele de deget simple, brățări din tablă de bronz, torques-uri, pandantivi cordiformi dubli, mărgele, inele de deget din sârme torsionate şi împletite, cruciuliță pectorală, brățară din bară, rombică în secțiune, brățări decorate la extremități cu motive zoomorfe). Una din cele două brățări cu motive zoomorfe (Pl. IV/57) (Réthy 1898, p. 128, 129-III. Tábla/1) se încadrează tipului 3b Kovács (Kovács 1994, p. 120).

\section{Transilvania}

1. Moldoveneşti (jud. Cluj). Mormânt individual de inhumație, orientat vest-est, descoperit în poziţia decubit dorsal, cu brațele pe abdomen. Inventar: lângă urechea dreaptă avea o verigă de păr din bronz, cu un capăt îndoit în formă de buclă simplă, la mâna stângă era o brățară din sârme de bronz torsionate (Pl. IV/58), cu terminații în formă de capete de animale. La mâna dreaptă a avut o altă brățară, din tablă de bronz, având capetele lăţite şi despărțite, decorate cu cercuri concentrice. Tot la capete avea şi două perforații. La gâtul scheletului avea un torques din sârme de bronz. A fost lucrat din sârmă pusă în trei. La craniu mai avea o verigă de păr, din bronz, cu un capăt îndoit în formă de $\mathrm{S}$, fără caneluri. Ca inventar mai avea şi un inel decorat prin crestare (Horedt 1954, p. 505, Fig. 8; Kovács 1994, p. 129; Roska 1914, p. 140, 141, 7. kép. 4 a - tipul 3b Kovács, M.XLII)

VI.c. Brățară din bară de bronz turnată, imitând torsadarea, cu terminații zoomorfe, despărțite.

\section{Crişana}

1. Vărşand-Movila dintre vii (jud. Arad); achiziție (Pl/ IV/59) (Popescu 1956, p. 133, Fig. 90/1; M.N.I.R. Inv. Nr. 17208-17209. Kovács o consideră de tipul $3 \mathrm{a}$, dar piesa este turnată nu din sârme. Kovács 1994, p. 123) tipul 4a Kovács.

2. Foeni (Jud. Bihor). Mormânt individual de inhumație, în poziția decubit dorsal, orientat VNV-ESE. Inventar: la tâmple două verigi de păr cu terminațiile depărtate (una circulară în secțiune, cealaltă lenticulară, ambele de dimensiuni diferite), două verigi de păr cu un capăt în formă de $\mathrm{S}$, la antebrațul drept o brățară din bronz (Pl. IV/60) care imită torsionarea (tipul 4a, Kovács), având capetele decorate cu motive zoomorfe, iar la mâna stângă, pe deget avea un inel decorat cu motiv crestat (Németi 2001, p. 228-3. kép/2, p. 233).

\section{Dobrogea}

1. Dinogeția (com. Jijia, jud. Tulcea) (Pl. IV/61). Nu a fost găsită în context stratigrafic clar - tipul 4a Kovács (Dumitriu 2001, p. 63, Taf. 64//7). 
VI.d. Brățară din bară de bronz, imitând torsionarea, cu terminații în formă de capete de animal, unite între ele

\section{Crişana}

1. Roiori (Jud. Bihor). Piesa se încadrează în tipul 4 b Kovács. (Fehér, Éry, Kralovánsky 1962, p. 36; Kovács 1994, p. 120)

Pe lângă aceste brățări, în Banat, în zona iugoslavă precum şi în colțul extrem din nordvest (comitatul Csongrád) a mai fost descoperit încă un tip de brățări confecționate dintr-o sârmă de bronz, pusă în trei, cu ochiuri sau bucle la ambele capete. În interiorul fiecărui ochi, capătul sârmei a fost îndoit în formă de buclă. Astfel de piese au fost descoperite la Szöreg-Homokbánya (M.A şi M.38; Bálint 1991, p. 78, Taf.XXIII/11， p. 79， 92, Taf.XXXI/21, p. 93), Banatsko Aranđjelovo (un exemplar), Bočar (un exemplar; Stanojev 1989, p. 15, 17, 33, 35) şi la Novi Kneževac (Hampel 1907, p. 149, tab.38/A/2). Acest tip de brățări este destul de răspândit în interiorul arcului carpatic, în special în secolul X. În sudul Dunării, ele nu au fost găsite până în prezent și sunt specifice în special Pannoniei. De asemenea, prezența lor nu a fost încă semnalată nici în Transilvania. Din păcate, în Banat nu sunt cunoscute decât foarte puține complexe intacte din care au fost recuperate astfel de piese. De, regulă ele se asociază cu piese care au fost considerate ca fiind maghiare timpurii. Este greu de spus care este originea lor, dar faptul că au fost descoperite doar în complexe funerare din Pannonia, vine să confirme că sunt piese tipice acestei regiuni în secolul $X$ şi eventual de la începutul secolului XI.

Se observă că primul tip de piese, indiferent de perioada în care au fost încadrate cronologic, se concentrează din punct de vedere geografic pe linia Dunării, sau la mică distanță de aceasta (vezi harta 2). În Ungaria actuală au fost descoperite doar în mod excepțional, la Örspuszta. Încadrarea cronologică a mormintelor de acolo a fost realizată pe baza acestor piese, în secolele X-XI (Fülöp, Jungbert 1983, p. 233-234). În Banat ele se concentrează doar în regiunea montană, în colțul sud-estic. În
Oltenia le găsim de asemenea, preponderent, în partea de vest, deci într-o regiune apropiată Banatului. Cele mai multe analogii pentru acest tip de piese le găsim la sudul Dunării, în teritoriul actual al Bulgariei şi Iugoslaviei. Datarea lor este foarte diversă, în funcție de regiune.

Încadrarea lor cronologică este foarte diversă, începând din secolul X până în veacul XIV în Bulgaria de exemplu (Gatev 1977, p. 38 , Fig.5/VII, p. 40), dar cu precizarea că în necropole ele apar cu predilecție în sec. XI-XII (Džambov 1977, p. 56, 58, Fig. 2/a-datată în secolele X-XI la Hisar). În Iugoslavia, în special în bazinul Dunării, aceste piese au fost datate în secolele XI-XII: Ribnića-secolul XII (Minić 1982-1983, T.IV/1), Braničevo-Svetinjesecolele XI-XII (Popović, Ivanisević 1988, p. 164, fig. 34/12, 13), Korbovo-Pesak-a doua jumătate a secolului XII şi XIII (Radojčic 1986, p. 135, 141, Fig.7/1; M.2), Korbovo şi Prahovosecolele XI-XII (Janković 1973-74, p. 227241), Djerdap-Brza Palanka-secolul XII (?;Pavlović-Ercegović 1966, p. 143-152, Pl. II, Fig. 11-12, Pl. IV, Fig. 6-7, Pl. V, Fig. 1-4), Požarevac-sec. XII, prin asociere cu o monedă emisă în timpul domniei lui Manuel Comnen (Marjanović 1967, p. 217-220, Pl. 1-2), Popovac în secolele XI-XII (Milošević 195859 , p. 129) şi la Trnjane în secolele XI-XIII (Marjanović-Vujović 1986, după datarea generală a necropolei), Vajuga-Pesac-necropola nr. 2-secolele XI-XII (Premk, Popović, Bjlejalac 1984, p. 123, Fig. 104/ 6, MarjanovićVujović 1986, p. 184-237). În această din urmă localitate au fost găsite în M109 (în asociere cu brătări din platbandă şi din bară circulară în secțiune, lățită la capete, verigă de păr), iar în M19 (în asociere cu o lamă de cuțit şi o verigă de păr).

În Banat cel mai probabil au pătruns în a doua jumătate a secolului XII şi au fost utilizate şi în următorul. Ele sunt tipice acolo, doar unui număr limitat de necropole (Gornea-Căunița de Sus, Cuptoare-Sfogea şi Şopotu VechiMârvilă). O piesă a fost descoperită şi în necropola de la Caransebeş-Centru, dar nu se poate spune cu exactitate dacă este o brățară din sârme torsionate, de acelaşi tip. Trimiterea pentru analogie la o piesă similară din Muzeul Banatului Montan-Reşiţa oferită de autorul 
cercetării nu corespunde ca număr de inventar şi nici ca număr de mormânt-M. 306 (Bona 1993, p. 93). Nu este exclus să fie vorba de o greșeală de tipar, și să avem de-a face cu un alt mormânt, posibil cu 106 care a avut în inventar o astfel de brătară din sârme de bronz torsionate (Țeicu 1993, p. 233). De altfel, necropolele menționate au caracteristici comune din punct de vedere al ritualului de înmormântare şi al pieselor depuse în morminte. Acest tip nu a apărut niciodată în cimitire în care au fost descoperite morminte cu arme, cai sau piese de harnaşament. De altfel, diferența între brățările executate din sârme torsionate, găsite în necropolele analizate din sudul Banatului, şi cele din orizontul funerar de tip Bielo Brdo a fost semnalată încă din 1972 într-un articol apărut la Belgrad şi semnat de către Slavenka Ercegović-Pavlović. În articolul în cauză se precizează clar că acest tip de brățări sunt caracteristice Serbiei, Bulgariei şi Macedoniei (Ercegović-Pavlović 1972, p. 41-58).

Piesele care se asociază acestor podoabe sunt de regulă de factură sud-dunăreană (brățări de sticlă, brățări care au capete lățite, cercei decorați în tehnica filigranului, cercei cu astragali, cercei de tâmplă cu montură biconică, cercei cu montură sferică). Doar în două cazuri ele au apărut în combinație cu piese tipice orizontului funerar de tip Bielo-Brdo (M. 48 de la Gornea-Căunița de Sus şi M.291 de la Cuptoare-Sfogea-verigi de păr cu un capăt îndoit în forma literei S). În cazul lui M. 48 de la Gornea- Căunița de Sus, în articolul apărut în revista Banatica 13/1/1993, la pagina 297 autorii cercetării nu menționează veriga de păr cu un capăt îndoit în formă de $S$, dar în monografia Gornea, apărută la Reşița în anul 1996, la pagina 85 şi la 86 , fig. $51 / \mathrm{M} 48$ d este ilustrată o astfel de piesă, dar al cărei capăt este rupt. Tipul capătului verigii de la CuptoareSfogea nu a fost descris, dar este foarte probabil să nu fi avut caneluri (diametrul său este de 2 $\mathrm{cm})$. Aceasta poate demonstra că aceste necropole sunt contemporane cu cele de tip Bielo-Brdo. Conform tipologiei lui Giesler (tipul II, 4/2; Giesler 1981, p. 40, Abb.7a), aceste piese se pot data din anii ' 30 ai secolului XI până la începutul secolului XII. În acest stadiu al cercetării nu putem să ne pronunțăm dacă în zona montană a Banatului avem de-a face în cazul acestor necropole cu piese de import preluate de populația de acolo ca o modă, ori este vorba de cimitire în care s-au înhumat indivizi cu un etnic divers. Lipsa unei datări absolute al acestor piese prin monede, nu ne permite să datăm cu mare exactitate intervalul cronologic în care au fost în uz aceste piese la nordul Dunării. Totuşi nu trebuie exclusă nici posibilitatea ca ele să îşi aibă începuturile la sfârşitul secolului al XI-lea. În acest sens trebuie să avem în vedere două elemente: prezența verigilor de păr cu un capăt îndoit în forma literei $\mathrm{S}$ şi care nu au caneluri pe partea aplatizată şi prezența unei monede emisă în timpul regelui Coloman (1095-1116), găsită în necropola de la Şopotu Vechi-Mârvilă. La aceasta se adaugă faptul că necropole similare ca structură şi piese de inventar au fost în funcție pe malul drept al Dunării încă din secolul XI. Se poate observa faptul că la nordul Dunării, dar numai în zona de munte a Banatului, au funcționat un anumit tip de necropole care au elemente de ritual în mare parte diferite de cele din zona de câmpie. Tipurile de piese descoperite sunt în mod frapant diferite de cele descoperite în necropolele din zona de câmpie a aceleiaşi regiuni, fiind în mare parte de tradiție bizantină. Se poate observa că acest orizont de necropole a încetat să mai fie sesizat prin caracteristicile sale la nivelul pieselor de podoabă de la o dată încă neclară, de după începutul secolului XIII. Momentul poate avea mai multe cauze, legate în special de pătrunderea marilor feudali ai regatului în zona montană, precum şi de ofensiva catolicismului la nivelul întregii Ungarii. Dispariția acestor obiceiuri de depunere a unui anumit tip de piese în morminte, este sesizabilă şi pentru orizontul funerar de tip Bielo Brdo, care după data menționată nu mai este nici el sesizabil prin caracteristicile sale la nivelul inventarului (Există piese tipice, precum verigile de păr cu un capăt îndoit în formă de $S$, care au mai fost descoperite şi în morminte mai târzii, dar acestea constituie excepții şi nu un fenomen general). Ambele orizonturi funerare au avut în parte cauze comune de dispariție, probabil în special de ordin religios. Pe alocuri, sporadic, astfel de elemente de manifestare funerară (depunerea unor piese de podoabă tipice acestor 
două orizonturi) se mai sesizează, dar nu au mai avut intensitatea precedentă. Se poate observa încă un fenomen legat de acest nou fenomen surprins la începutul secolului XIII, anume abandonarea în bună parte a mai vechilor necropole şi apariția unora noi, care prezintă alte caracteristici din punct de vedere al depunerii pieselor de inventar. În necropolele de la sudul Dunării, aceste brățări nu au fost găsite decât extrem de rar în asociere cu verigi de păr cu un capăt îndoit în forma literei S, ca de exemplu M.252 de la Trnjane (MarjanovićVujović 1986, p. 42, Pl.XVI/M.252).

Piesele I a (cele care au avut fir filigranat printre cele de bază) sunt ceva mai puțin cunoscute. Ele au apărut doar în necropola de la Şopotu Vechi-Mârvilă şi au fost datate în secolul XII (Țeicu 1993, p. 246).

Analiza combinatorie a brățărilor din tipul I şi Ia, demonstrează că în cele mai multe cazuri ele au fost găsite în asociere cu piese de proveniență sud-dunăreană, după cum urmează: cercei decorați cu filigran (un caz la CuptoareSfogea), cercei decoraţi cu astragali (cinci cazuri la: Gornea-Căunița de Sus-1, Sopotu Vechi-Mârvilă-2, Cuptoare-Sfogea-2), cercei cu montură biconică pe verigă (Gornea-1, Sopotu Vechi-1), cercei cu o sferă pe verigă (CuptoareSfogea-1), inele decorate cu motive zoomorfe care nu au analogii în orizontul funerar de tip Bielo Brdo (Gornea-Căunița de Sus-1, Cuptoare-Sfogea-1), brățări de sticlă (CuptoareSfogea-1). În alte trei cazuri nu au avut asociate alte piese de inventar. Piesele care ar putea fi comune sau care au analogii şi în orizontul funerar de tip Bielo Brdo sunt nasturii (Cuptoare-Sfogea-1, dar piesa nu a fost publicată) şi colierele de mărgele în combinație cu scoici kauri (Gornea-Căunița de Sus-2). Trebiue menționat că la nordul Dunării, în Banat şi Vojvodina piesele de producție suddunăreană din variantele amintite sunt destul de rare. S-au găsit cercei cu o sferă pe verigă, asemenea pieselor de la Cuptoare-Sfogea doar în necropola de la Nosa, în M.4/48 (Stanojev 1989, p. 72, 80/379, 380). Datarea lor este însă foarte largă, din secolul XI până în prima jumătate a secolului XV. Pe baza descoperirilor de piese similare din sudul Dunării de la Prahovo, Trnjane şi Vinča acești cercei au fost datați în cursul secolului XII. La Dobrača în M.
24, acest tip de piesă a apărut în asociere cu o verigă de tâmplă cu mulură circulară (Garašanin, Garašanin 1956, p. 200, Fig. 11/b). Datarea mormintelor este relativă, în secolele X-XII sau XIII-XIV.

O altă caracteristică a acestor morminte cu piese de inventar de proveniență suddunăreană este lipsa monedelor. În aceste trei necropole prezența monedelor maghiare, cu o singură excepție (Şopotu Vechi-Mârvilăa, unde a fost descoperită o piesă emisă în timpul regelui Coloman-1095-1116) au apărut abia de la începutul secolului XIII. Cu excepția amintită, primele monede sunt bizantine, începând din timpul domniei împăratului Ioan II Comnenos (1118-1143). Aceasta ar putea demonstra că aceste necropole îşi au începutul în secolul al XII-lea. Prezența verigilor de păr cu un capăt îndoit în forma literei „S”, ar putea fi un argument în favoarea începutului de secol XII. Tipologia făcută de Giesler pentru aceste piese nu se poate aplica în zona de SE a Banatului. Verigile de păr menționate (tipul II/5-6 după Giesler) nu au fost descoperite încă în acest spațiu, ci doar tipurile I şi II conform aceluiaşi autor. Dacă am avea în vedere doar aceste piese, începuturile celor trei necropole ar trebui căutate în jurul anului 970 p. Chr. până spre mijlocul secolului XI. Lipsa şi a altor elemente ale orizontului funerar de tip Bielo Brdo, mă face să cred că este vorba de o rămânere în uz a acestor piese în colțul de SE al Banatului. Dacă adăugăm şi lipsa totală a pieselor de armament din mormintele cercetate în cele trei necropole, putem afirma că partea montană a fost la limita orizontului funerar Bielo Brdo, din punct de vedere al prezenței acestor piese specifice. Prezența masivă a podoabelor de proveniență sud-dunăreană marchează mai degrabă existența unui alt orizont funerar, acelaşi cu cel prezent pe malul drept al Dunării, în porțiunea corespondentă Banatului actual şi Județului Mehedinți.

Din punct de vedere al ritului mormintele care au avut acest tip de inventar sunt fără excepție de inhumație.

La nivelul ritualului, s-a constatat prezența diverselor orientări (VE: M.92 şi 106 de la Cuptoare-Sfogea, şi M. 16 şi 27 de la Şopotu Vechi-Mârvilă, NV-SE: M. 44, 48 de la GorneaCăunița de Sus şi M. 12 de la Şopotu Vechi- 
Mârvilă, SV-NE: M. 59 de la Gornea-Căunița de Sus şi M. 28 de la Şopotu Vechi-Mârvilă).

Poziția defuncților în cazurile în care mormintele nu au fost deranjate a fost decubit dorsal.

Brațele au avut diverse poziții, fără o regulă anume. Aceste poziții sunt: A (cu brațele pe lângă corp)-M.16 de la Şopotu VechiMârvilă, B (cu palmele depuse pe bazin)-M. 291 de la Cuptoare-Sfogea, D (cu brațele pe torace)-M.8 de la Cuptoare-Sfogea şi M. 48 de la Gornea-Căunița de Sus, E (cu mânile flectate din cot şi palmele aduse pe clavicule)-M.44 de la Gornea- Căuniţa de Sus. Se adaugă şi subvarianta $\mathrm{BC}$ (o palmă depusă pe bazin iar cealaltă mână pe abdomen) care este tipică doar pentru sudul Banatului şi apare regulat doar în cazul siturilor de la Cuptoare-Sfogea şi GorneaCăunița de Sus. În cazul poziției BD (un braț cu palma pe bazin şi celălalt pe torace), surprinsă la M.59 de la Gornea- Căunița de Sus, este vorba cel mai probabil de un accident produs la înmormântare, la fel ca şi în cazul lui M.303 de la Cuptoare-Sfogea care avea o mână pe torace, iar cealaltă pe abdomen. Având în vedere aria de răspândire la nordul Dunării a brățărilor din tipul I a şi b, în Banatul estic şi Oltenia, precum şi faptul că se asociază cu piese tipice bizantine sau de influență bizantină în număr mare, putem crede că în aceste teritorii, în secolele XI, XII şi primii 30 de ani ai secolului XIII, putem vorbi aici de o puternică influență bizantină apoi al celui de-al doilea Țarat bulgar, dacă nu chiar de un control al acestor state în spațiul studiat.

Piesa din tipul II a provine dintr-un mormânt de războinic care pe baza descrierii inventarului nu se poate data foarte clar (Popescu 1956, p. 132, Fig.88), el putând aparține şi celei de-a doua jumătăți a secolului $\mathrm{X}$, dar şi primei jumătătii a veacului următor.

Piesele din tipul II b (Vărşand-Movila dintre vii şi Dinogeția) provin din contexte neclare. Şi nu pot fi decât încadrate cronologic cu o anume aproximație în secolul XI. Având în vedere aria de răspândire a acestor piese, se poate spune că au fost comune atât necropolelor din perioada cuceririi patriei, respectiv regatul Ungariei, cât şi Imperiului bizantin. Din teritoriul maghiar astfel de piese au fost descoperite la Majs-Udvari rétek (Kiss 1983, p.
111, 166, 79. ábra /3). Acestea se asociază în cazul lui M. 533 cu mărgele (Kiss 1983, p. 160, 73. ábra/27). În Imperiul bizantin astfel de piese au fost găsite la Braničevo-Svetinje (Popović, Ivanisević 1988, p. 164, Fig. 34/14, 15). Se poate observa că sunt de regulă în zona de contact dintre Imperiu şi diversele populații de stepă, iar frecvența lor este redusă atât în Pannonia cât şi în Balcani, ceea ce ar putea sugera că sunt piese care se întâlnesc în special la grupele de populație din zona de contact între diversele culturi materiale ( $\mathrm{Au}$ apărut în necropole din orizontul sud-dunărean şi în cele de tip Bielo Brdo ca de exemplu la Vărşand şi Braničevo, în zona de contact dintre ele, precum şi în zone cu populații amestecate de la Dunărea de Jos. Faptul că sunt puține numeric, precum şi aria lor de răspândire şi modul de execuție pot indica faptul că sunt mai degrabă imitații ale celor din două sârme pliate în două şi torsionate, cu două bucle la capete).

Tipul III este tipic orizontului funerar de tip Bielo Brdo, faza I conform cronologiei realizate de J. Giesler. În sprijinul acestei afirmații sunt cerceii descoperiți în M.1 din necropola B de la Blandiana şi cerceii cu un capăt îndoit în forma literei $\mathrm{S}$ de la VărşandMovila dintre vii. În primul caz, brăţările au fost datate în secolul X (Ciugudean, Dragotă 2002, p. 9, 54/132, 133). În cazul necropolei de la Vărşand, asocierea brățării cu o verigă de păr cu un capăt îndoit în forma literei $\mathrm{S}$, urcă datarea acestui tip de piesă foarte probabil până spre anii '30 ai secolului XI. De remarcat că acest tip de brăţară este unul rar întâlnit, pe teritoriul actual al României fiind descoperite doar trei piese. De asemenea nu au fost descoperite piese similare nici în Banatul iugoslav, Vojvodina sau în zona sud-dunăreană.

Tipul IV a are analogii în spațiul maghiar, ca de exemplu în Comitatul Baranya, la SzárászSzlavónia-dülö (Kiss 1983, p. 285, 286, 152. ábra/17), Ecséd-Comitatul Heves (Hampel 1907, p. 164, 53. tábla/1, 2), Bač (Stanojev 1989, p. 22, $23 / 112,113)$. Pe baza pieselor recuperate din necropolă, piesa poate fi datată la sfârşitul secolului X şi prima jumătate a următorului. El se poate data asemenea tipului III.

Tipul IV b a fost datat unitar. Atât în cazul descoperirii de la Mirnopole (Spinei 1985, p. 112, 122, 200, Fig. 28/1) cât şi la Alba- 
Iulia (Horedt 1958, p. 52, Abb.13/5), piesele au fost datate cu mare probabilitate în secolul XI.

Tipul IV c, reprezentat prin două piese (achiziție din 1910 de la Blandiana şi una descoperită la Alba Iulia), au fost datate în secolul XI. Piesele provenite din acest sit au fost considerate ca aparținând orizontului funerar de tip Bielo Brdo (Horedt 1958, p. 113. Piesele achiziționate în 1910, nu sunt însă neapărat relevante orizontului funerar de tip Bielo Brdo, dar nici orizontului stepic. Piesele recuperate $\mathrm{cu}$ acea ocazie sunt irelevante din punct de vedere al atribuirii lor unei anumite populații. Verigile de păr simple se întâlnesc pe o arie extinsă în sud-estul Europei în secolele IX-XI. În aceeaşi situaţie se află şi mărgelele). Inventarul general al necropolei (de la Blandiana) indică mai degrabă orizontul vechi maghiar, dar nu trebuie să excludem nici prezența în necropolă şi a altor grupe de populație. Cercei asemănători, ornamentați cu muluri circulare în jurul verigii şi cu pandantiv decorat în tehnica granulației şi filigranului au mai fost descoperiţi şi în alte necropole datate în cursul secolului X, ca de exemplu la Alba Iulia-Stația de salvare, Novi Kneževac (P1.3/11; Hampel 1907, p. 149, 38.kép.6) şi Cluj-Str. Dostoievski (Spinei 1999, p. 66, Fig.14/6). În această din urmă localitate, perechea de cercei a fost descoperită în asociere cu o sabie din prima jumătate a secolului X. Aceasta vine să confirme încă o dată că aceşti cercei au circulat în special în cursul secolului $\mathrm{X}$, deci şi brățara amintită se poate data similar.

Tipul IV d este reprezentat prin piese care în literatura română de specialitate au fost considerate ca aparținând orizontului funerar de tip Bielo Brdo şi culturii Răducăneni (Cultura Răducăneni a fost atribuită cumanilor de către D. Gh. Teodor (vezi Teodor 1963, p. 202). În Transilvania piesele au fost datate în secolul X, iar în Moldova în secolele XI-XII. Un fragment de piesă de acest tip a mai fost descoperit şi la Szárász-Szlavónia-dülö (Kiss 1983, p. 285, 286, 152. ábra/16), un altul a fost descoperit la Tőke, în Comitatul Csongrád (Hampel 1907, p. 209, 88. tábla. 1), Székesfehérvár-Demkóhegy (Hampel 1907, p. 199, 81. tábla/18 sír/1). Având în vedere această situație, subvarianta de brățări amintită, trebuie considerată ca fiind tipică populațiilor de stepă şi au avut o circulație pe o arie mai largă, fie piesa de la Răducăneni se datează anterior secolele XI-XII.

Tipul V este reprezentat de piese descoperite la Vărşand-Movila dintre vii. Acest tip de piese, împletite, cu ochi, respectiv cârlig la capăt a fost considerat ca fiind tipic primei faze a orizontului funerar de tip Bielo Brdo. Datarea lor este destul de largă, de la jumătatea secolului X până la mijlocul veacului XI. Asemenea piese mai provin din descoperirile de la Siklósnagyfalu-Comitatul Baranya (Kiss 1983, p. 270, 271, 140. ábra 17), SzékesfehérvárDemkóhegy (Hampel 1907, p. 206, 87. ábra/B/1), Gombos (Bogojevo)-M.28 (Stanojev 1989, p. 25, 28/136), Bielo Brdo (Hampel 1907, p. 158, 46. tábla/4), Črna Bara (Stanojev 1989, p. 129, 130/708). Acest tip de brățări au fost în general datate în secolele X-XI, dar ar trebui remarcat că predomină în necropolele din secolul XI, fiind foarte rare în cele timpurii.

Tipul VI a (corespunde tipului III a, Kovács). Aceste piese au fost datate începând din prima jumătate a secolului $X$ până la mijlocul celui următor. În funcție de sit, pot fi făcute anumite nuanțări cronologice. De exemplu la Majs (com Baranya) în M. 942 (Kiss 1983, p. 138, 165, 78. ábra/5, 391, 83 tábla, 942 sír), a apărut în asociere cu o verigă de păr cu un capăt îndoit în forma literei $\mathrm{S}$, dar şi cu mărgele similare cu cele din M. 14 de la Hodoni-Pocioroane (Draşovean, Țeicu, Muntean 1996, p. 36139, Pl. LXI/5). În M.53 din aceeaşi localitate a apărut în asociere cu o brățară simplă din bară de bronz (Kiss 1983, p. 80, 81, 53 ábra., p. 166, 79. ábra/1), o oală borcan (Kiss 1983, p. 150, 66. ábra 53 sír), mărgele, nasturi (Kiss 1983, p. 160, 73. ábra/21, $39,47,48)$, pandantiv în formă de semilună, cordiform dublu (Kiss 1983, p. 161, 74. ábra/1, 12), inel (Kiss 1983, p. 162, 75. ábra/17). În acelaşi comitat Baranya, în localitatea ZmajevacKigiós a fost descoperită o piesă similară (Kiss 1983, p. 70, 44. ábra/23, p. 273).

Tipul VI b (corespunde tipului III b, Kovács) şi a fost datat până la începutul secolului XI. La Moldoveneşti, pe baza pieselor care au mai fost descoperite în mormânt, poate fi atribuită orizontului funerar de tip Bielo Brdo, faza I.

Tipul VI c (corespunde tipului 4 a, Kovács). Acesta a apărut atât în bazinul carpatic, cât şi la sudul Dunării. Cu mici 
deosebiri, ținând de ornamentare, se poate spune că sunt piese care au circulat în Pannonia, Transilvania, cât şi în Imperiul Bizantin. Exemplarul de la Dinogeția a fost datat în a doua jumătate a secolului XI (Dumitriu 2001, p. 63, Taf. 7/9), însă se circumscrie unei alte arii de circulație, neputând fi pus pe seama prezenței maghiarilor.

Tipurile VI d (Kovács 1994, p. 135, Abb.31, p. 136) este, de asemenea, tipic bazinului carpatic. Ultimul tip este specific secolului XI, fiind datat şi cu monede din aceeaşi perioadă.

Putem spune că aceste tipuri de brățări, din sârme de bronz sau de argint torsionate sau împletite, precum şi imitațiile lor din bară de bronz, în funcție de tipologie, se circumscriu de regulă unui anumit spațiu de circulație şi unui anume interval cronologic. $\mathrm{Cu}$ puține excepții (brățările decorate la capete cu motive zoomorfe), răspândirea lor este tipică pentru anumite state medievale sau, în cazul în care acestea încă nu existau, unor anumite populații. Cazurile în care putem bănui că sunt piese de import sunt extrem de rare (de exemplu la Örspuszta), şi nici măcar acelea nu sunt sigure. $\mathrm{Nu}$ trebuie însă ca prin granițele unui stat să înțelegem şi o populație cu un anume etnic, ci existența unor orizonturi de înmormântare care sunt specifice pentru un interval cronologic unui spațiu politic dat. Obiceiurile de înmormântare diferite de la un orizont funerar la altul, în care apar anumite tipuri de piese, precum şi inventarul care li se mai asociază, constituie un argument în plus în favoarea faptului că unele tipuri de brățări sunt preferate de unele populații şi pot fi întâlnite doar la ele. De altfel, aceste brățări sunt podoabe comune în cele mai multe cazuri şi nu reprezentau bunuri de prestigiu care circulau în mod deosebit. Descoperirea lor în unele cazuri la o distanță mai mare de granițele unui stat căruia îi sunt specifice, are un caracter mai degrabă întâmplător.

Brățările decorate la capete cu motive zoomorfe, dată fiind aria lor foarte mare de răspândire, în interiorul arcului carpatic şi la Dunărea de Jos, la sudul ei în special, poate fi pusă în legătură cu prezența populațiilor de stepă şi poate se leagă de anumite credințe (Pentru secolele X-XIII, este greu de spus dacă mai aveau rol apotropaic sau au fost simple podoabe. Dacă aveau rol apotropaic, trebuie să avem în vedere existența unor credințe comune sau asemănătoare la populațiile din interiorul arcului carpatic şi la unele comunități din estul Peninsulei Balcanice). Este dificil de spus în acest moment dacă decorul capetelor a fost preluat din lumea bizantină, sau influența s-a produs în sens invers. Ceea ce putem spune este faptul că stilistic se pot observa diferențieri între piesele din interiorul arcului carpatic şi cele de la Dunărea de Jos. Revenirea Bizanțului la Dunărea Mijlocie, în secolul XI, este posibil să fi influențat şi acest segment al orfevrăriei din interiorul arcului carpatic pentru piesele târzii. Ar mai fi de remarcat şi faptul că aceste podoabe nu sunt des întâlnite în necropolele vechi maghiare, ci mai degrabă sunt sesizabile abia din ultimul sfert al secolului X. Piese asemănătoare au fost însă frecvente în Pannonia în timpul stăpânirii avare. Se poate observa însă că sunt extrem de rare în sudul şi estul Serbiei, ori în Dalmația. Aceasta, ar putea marca faptul că nu pot fi puse în conexiune cu o productie a lor în mediul slav de acolo, sau de eventuale credințe a acestor populații legate de rolul lor apotropaic. Interesant este faptul că un mare număr se concentrează în mediul macedonean sau est şi sud bulgar. Interesant este faptul că mormintele care au avut ca inventar astfel de piese au fost considerate de către unii cercetători bulgari ca aparținând unor comunități creştine (Văžarova 1971, p. 1-23. În împărțirea pe grupe şi subgrupe a necropolelor, cercetătoarea din Bulgaria consideră că aceste morminte aparțin grupei II, sub-grupa 2 şi aparțin unei populații creştine, slave, din secolele IX-XI). Pentru spațiul arcului carpatic, acest fapt nu poate fi susținut $\mathrm{cu}$ argumente solide. 


\section{BIBLIOGRAFIE}

Barnea 1967 - I. Barnea, Dinogeția, Bucureşti, 1967.

Bona 1993 - P. Bona, Biserica medievală din Caransebeş, Caransebeş, 1993.

Ćorović-Ljubinković 1956 - M. Ćorović-Ljubinković, La nécropole slave de Brestovik, în Archaeologia Jugoslavica 2, 1956, p. 131-137.

Ciugudean 1996 - H. Ciugudean, Catalogue of exhibition. The Year One Thousand at Alba Iulia-between history and archaeology, Alba Iulia, 1996.

Ciugudean, Dragotă 2002 - H. Ciugudean, A. Dragotă, Catalogul expoziției: Civilizația medievală timpurie din Transilvania: rit şi ritual funerar în secolele IX-XI, Alba Iulia, 2002.

Dragotă et alii 2003 - A. Dragotă et alii, Tipuri de brățări în cimitirele de secol X-XI, Patrimonium Apvulense 3, 2003, p. 89-112.

Džambov 1977 - I. Džambov, Parures médiévales de Hisar (X-XIe s.), Arheologia, 3, 1977, p. 56-59.

Dumitriu 2001 - L. Dumitriu, Der Mittelalterliche Schmuck des Unteren Donaugebietes îm 11.-15. Jahrhundert, Bucureşti Ercegović-Pavlović, Sl. Contribution a l'Etude des Nécropoles médiévales en Serbie, Starinar, 17, 1966, p. 143-152.

Ercegović-Pavlović 1970 - Sl. Ercegović-Pavlović, Contribution à l'Étude des Boucles d'oreilles en Serbie du IX-e au XIII-e Siécle, Starinar, 2, 1970, p. 41-58.

Fehér, Éry, Kralovánsky 1962 - G. Fehér, K. Éry, A. Kralovánsky, A közép Duna medence magyar honfoglalás- és kora Árpád-kori sírleletei. Leletketaszter, In: Rég. Tán., 2, Budapest, 1962.

Fülöp, Jungbert 1983 - Gy. Fülöp, B. Jungbert, Örspuszta-ein Gräberfeld aus der Landnahmezeit und der Frühen Arpadenzeit, Alba Regia, 20, 1983, p. 234.

Gatev 1977 - P. Gatev, Parures de sépultures des Xie-XIIe s., Arheologia, kniga 1, anul XIX, 1977, p. 30-46.

Garašanin, Garašanin 1956 - M. Garašanin, D. Garašanin, La Nécropole serbe médiévale de Dobrača, Starinar 5-6, 1956, 191-204.

Giesler 1981 - J. Giesler, Untersuchungen zur Chronologie der Bijelo Brdo-Kultur. Ein Beitrag zur Archäologie des 10. und 11. Jahrhunderts im Karpatenbeken, In: Praehistorische Zeitschrift, 56. Band, Heft 1, Walter de Gruyter, Berlin. New York, 1981.

Hampel 1900 - J. Hampel, A honfoglalási kor hazai emlékei, In: A magyar honfoglalás kútfői, coordonatori Pauler Gy.-Szilágy S., Budapest, 1900.

Horedt 1954 - K. Horedt, Şantierul arheologic Moreşti (reg. Tg. Mureş, Reg. Aut. Maghiară), SCIVA 5, 1954, 12, p. 199-231.

Horedt 1966 - K. Horedt, Die Ansiedlung von Blandiana, Rayon Orăştie, am Ausgang des ersten Jahrhundert $u$. Z, Dacia N.S., 10, 1966, p. 261-289.

Janković 1973-74 (apărut în 1975) - M. Janković, Deux nécropoles médiévales en Serbie de l'est, Starinar XXIV-XXV, 1973-1974, p. 227-241.

Kiss 1983 - A. Kiss, Baranya megye X-XI. Századi sírleletei, Budapest, 1983.

Kovács 1994 - L. Kovács, Das Früharpadenzeitliche Gräberfeld von Szalbocs, Varia Archaeologica Hungarica, 6, Budapesta, 1994.

Lazarovici, Maxim, Țeicu, Oprinescu 1993 - Gh. Lazarovici, Z. Maxim, D. Țeicu, A. Oprinescu, Şantierul arheologic Gornea, 1989, Banatica, 12/1, 1993, p. 295-319.

Marjanović 1967 - G. Marjanović, Un tombeau médiéval des environs de Požarevac, Starinar, 18, 1967, p. $217-220$

Marjanović-Vujović 1984 - G. Marjanović-Vujović, Trnjane. Serbian necropolis (11th-13 th century), Beograd, 1984.

Marjanović-Vujović 1986 - G. Marjanović-Vujović, Vajuga-Pešac. La nécropole médiévale II, Cahiers des Portes de Fer, 2, 1986, p. 184-237.

Milošević, Desanka 1958-59 - Milošević, Desanka, Fouilles de conservation à Popovac, Zbornik Radova Narodnog Muzeja-Belgrad, 2, 1958-1959, p. 111-134.

Minić 1982-1983 - D. Minić, Ribnić, site prehistorique et antique. Agglomeration medievále avec Necropole, Starinar, 33-34, 1982-1983, p. 253-258. 
Németi 2001 - J. Németi, A mezöfényi (Foeni) Árpád-kori temetőrész rövid áttekintése, JAMÉ, XLIII, 2001, p. 225-238.

Németi 1986-1987 - J. Németi, Descoperiri arheologice din teritoriul localității Moftinu Mic (jud. Satu Mare), St.Com.Satu Mare, 7-8, 1986-1987, p. 101-137.

Oța 1998-2000 - S. Oța, Pièces inédites de la collection du Musée National D'Histoire de la Roumanie découvertes dans la nécropole du XI-e siécle de Vărşand-Movila dintre vii (Dép. D'Arad), Cercetări Arheologice, 11/2, 1998-2000, p. 497-505.

Plantos 2003 - C. Plantos, 185. Brățară, în Necropolele oraşului Alba Iulia-din preistorie în zorii evului mediu, Alba Iulia, 2003, p. 52.

Popescu 1956 - D. Popescu, Cercetări arheologice în Transilvania II. Săpăturile de la Vărşand, M.C.A. 2, 1956, p. 89-152.

Popescu 1970 - M. M. Popescu, Podoabe medievale în Țările Române, București, 1970.

Popović, Ivanišević 1988 - M. Popović, V. Ivanišević, Braničevo, cité médiévale, Starinar, 39, 1988, p. 125-179.

Premk, Popović, Bjelajac 1984 - A. Premk, P. Popović, L. Bjelajac, Vajuga-Pesac. Fouilles de sondage de 1980, Cahiers des Portes de Fer, 2, 1984, p. 118-124.

Rădulescu, Gáll 2001 - Al. Rădulescu, E. Gáll, Das Landnahmezeitliche Gräberfeld von Temesvár (Timişoara)-Csókaerdö, Acta Arch. Acad. Sc. Hung., Tomus LII, 2001, Fasciculi 1-3, p. 155-193.

Réthy 1898 - L. Réthy, Két Árpádkori temető Arad megyében, Archaeologiai Értesitő, 18, 1898, p. 124-131.

Roska 1914 - M. Roska, Árpád-kori temetö Várfalán, Dolgozatok, 5, nr.1, 1914, p. 125-187.

Spinei 1985 - V. Spinei, Realități etnice şi politice în Moldova meridională în secolele X-XIII. Români şi turanici, Iaşi, 1985.

Spinei 1994- V. Spinei, Moldova în secolele XI-XIV, Chişinău, 1994.

Stanojev 1989 - N. Stanojev, Nekropolen aus dem 10.-15. Jahrhundert în der Vojvodina. 712 Katalogabschnitte. Katalog 1, Novi Sad, 1989.

Teodor 1963 - D. Gh. Teodor, Câteva observații în legătură cu căldările de lut descoperite la Răducăneni (r. Huşi, reg. Iaşi), SCIV, 14, 1, 1963, p. 197-205.

Toropu, 1976 - O. Toropu, Romanitatea târzie şi străromânii din dacia traiană sud-carpatică, Craiova, 1976.

Țeicu 1981 - D. Țeicu, Câteva considerații pe marginea unor podoabe medievale, AMN, 18, 1981, p. 491-500.

Țeicu 1991 - D. Țeicu, Cercetări de arheologie în necropola medievală timpurie de la Şopotu VechiMârvilă (jud. Caraş-Severin), Crisia, 21, 1991, p. 307-310.

Țeicu 1993 - D. Țeicu, Necropole medievale (sec. X-XIV) din sudul Banatului, Banatica, 12/1, 1993, p. 229-272.

Țeicu 1998 - D. Țeicu, Banatul montan în evul mediu, Timişoara, 1998.

Țeicu 2003 - D. Țeicu, Necropola de la Şopotu Vechi, Studii Istorice, Timişoara, 2003, p. 23-60.

Țeicu Lazarovici 1996 - Gh. Țeicu Lazarovici, Gornea. Din arheolgia unui sat medieval din Clisura Dunării, Reşița, 1996.

Uzum 1981 - I. Uzum, Necropola feudală timpurie de la Gornea-,,Căunița de Sus” (județul CaraşSeverin), Banatica, 6, 1981, p. 181-210.

Uzum 1987 - I. Uzum, Considerații pe marginea cercetărilor din anii 1983-1985 în necropola feudală timpurie de la Cuptoare-Sfogea (com. Cornea, județul Caraş-Severin), Banatica, 9, 1987, p. 281-315.

Văžarova 1971 - Ž. N. Văžarova, Slaves et Protobulgares à la lumière des données archéologiques, Arheologia, 1, 1971, p. 1-23.

Vulpe 1967 - Al. Vulpe, Necropola Hallstatiană de la Ferigele. Monografie arheologică, Bucureşti, 1967.

Žeravica, Žeravica 1977-78 (apărut 1979) - Z. Žeravica, L. Žeravica, Agglomeration Médievale à Popovica près de Negotin, Starinar, 28-29, 1977-1978, p. 201-212. 


\section{Abrevieri bibliografice}

Acta Arch. Acad. Sc. Hung. - Acta Archaeologica Academiae Scientiarum Hungaricae (Budapesta)

AMN - Acta Musei Napocensis (Cluj-Napoca)

JAMÉ - A Jósa András Múzeum Évkönyve

M.C.A. - Materiale şi Cercetări Arheologice (Bucureşti)

Rég. Tán. - Régészeti Tanulmányok (Budapesta)

SCIV - Studii şi Cercetări de Istorie Veche (Bucureşti)

SCIVA - Studii şi Cercetări de Istorie Veche şi Arheologie (Bucureşti)

St.Com.Satu Mare - Studii şi Comunicări Satu Mare (Satu Mare)

\section{LIST OF ILLUSTRATIONS}

Pl. I. Bracelets type I. 1-4 (after Țeicu 1993); 5-10 (after Țeicu 1998); 12-14 (after Țeicu, Lazarovici 1996). Without scale.

PI. II. Bracelets type I. 15 (after Țeicu, Lazarovici 1996); 16-22 (after Teicu 2003); 23-24 (after Țeicu 1981); 25-29 (after Dumitriu 2001). Without scale.

PI. III. 30-31 Bracelets type Ia (after Țeicu 2003); 32-34 Bracelets type II (after Popescu 1956; Oța 19982000; Dumitriu 2001); 35-37 Bracelets type III (after Popescu 1856; Ciugudean, Dragotă 2002); 38 Bracelet type IVa (after Oța 1998-2000); 39-40 Bracelets type IV b (after Spinei 1985; Horedt 1958); 41 Bracelet type IV c (after Horedt 1966); 42-43 Bracelets type IV d (after Spinei 1985; Ciugudean, Dragotă 2002); 44 Bracelet made of twisted wire from Vărşand. Without scale.

PI. IV. 45-46 Brățări din sârme torsionate (after Németi 2001, Spinei 1997), 47-50 Bracelets type V (after Oța 1998-2000); 51-54 Bracelets type VIa (after Popescu 1956, Rădulescu, Gáll 2001, Dragotă inedit); 55-58 Bracelets type VI b (after Réthy 1898, Hampel 1900); 59-61 Bracelets type VI c (after Popescu 1956, Németi 2001, Dumitriu 2001). Without scale.

PI. V. Types of bracelets.

PI. VI. Types of bracelets.

PI. VII. Types of bracelets.

PI. VIII. Types of bracelets.

PI. IX. Types of bracelets.

PI. X. Types of bracelets.

PI. XI. Other items.

PI. XII. Bracelets made of twisted wire and bracelets casted similar to twisted wire $\left(\mathrm{X}^{\text {th }}-\mathrm{XIII}{ }^{\text {th }}\right.$ centuries).

\section{Silviu Oța}

Muzeul Național de Istorie a României

Calea Victoriei 12, sector 3, Bucureşti

030026 România 